\title{
ÁAirman
}

Jurnal Teknik dan Keselamatan Transportasi

\section{Kajian Pendidikan Vokasi Lanjutan Jalur RPL Type A1 Kelas Kerjasama Politeknik Penerbangan Makassar dengan Politeknik Negeri Ujung Pandang

\author{
Study of Continued Vocational Education RPL Type A1 \\ State Polytechnic of Ujung Pandang
} \\ Class Cooperation with Makassar Aviation Polytechnic with}

\author{
Fatmawati sabur ${ }^{1}$, Ahmad bahrawi ${ }^{2}$, Firman ${ }^{3}$, Tomy Aprilianus ${ }^{4}$ \\ fatmawarisaburatkp@gmail.com, achawiex@gmail.com, \\ firman@poliupg.ac.id,tomygalaxyj1@gmail.com \\ Politeknik Penerbangan Makassar \\ Politeknik Negeri Ujung Pandang
}

\begin{abstract}
ABSTRAK
Rekognisi Pembelajaran Lampau (RPL) sesuai dengan peraturan perundangan mempunyai dasar hukum berdasarkan Peraturan Menteri (Permen) Ristekdikti nomor 44 tahun 2015, dan Permen Ristekditi nomor 83 tahun 2013 yang merupakan salah satu dasar pelaksanaan RPL. Tujuan Penelitian untuk mengevaluasi Program kerjasama jalur Rekognisi Pelmbelajaran Lampau type Al menjadi pilihan dikarenakan belum tersedianya program studi Diploma IV di 7 (tujuh) UPT Perhubungan Udara,sehingga capaian daya serap lulusan dapat terwujud dan nilai penganguran dapat ditekan dengan mengembangkan kompetensi peserta didik yang sesuai dengan kompetensi dasar yang di peroleh pada jenjang Pendidikan diploma III. Untuk memperoleh data/informasi berdasarkan gambaran empiris tentang studi evaluasi program RPL kelas kerjasama bagi lulusan Pendidikan boarding dengan menggunakan metode CIPP. Hasil Penelitian Pelaksanaan alih jendang dari program D.III dengan pola pendidikan system boarding program studi Teknologi Bandar Udara dan Teknologi Navigasi Udara ke program D.IV melalui jalur RPL type A dengan menerapkan metode pembelajaran Blended Learning dan non boarding pada program studi Teknik Mekatronika dan Teknik Listrik, dapat dilaksanakan dengan menempuh pendidikan sebanyak 33 - 42 SKS. Jumlah SKS praktik disesuaikan dengan pemenuhan capaian pembelajaran dari masing-masing program studi dan penyetaraan kurikulum dari jenjang D.III Politeknik Penerbangan Makassar diakui sebesar $100 \%$ untuk dapat melanjutkan pendidikan alih jenjang ke D.IV Politeknik Negeri Ujung Pandang.
\end{abstract}

Kata kunci: Rekognisi Pembelajaran Lampau; Kurikulum

\begin{abstract}
Recognition of Past Learning (RPL) in accordance with laws and regulations has a legal basis based on Ministerial Regulation (Permen) Ristekdikti number 44 of 2015, and Minister of Research and Technology Regulation number 83 of 2013 which is one of the bases for implementing RPL. The purpose of the study was to evaluate the Past Learning Recognition pathway cooperation program type Al as an option due to the unavailability of Diploma IV study programs at 7 (seven) Air Transportation UPTs so that the achievement of graduate absorption can be realized and the value of unemployment can be
\end{abstract}


suppressed by developing student competencies in accordance with basic competencies obtained at the diploma III education level. To obtain data/information based on an empirical description of the collaborative class RPL program evaluation study for boarding education graduates using the CIPP method. Research Results in The implementation of the transfer of jendang from the D.III program with the boarding system education pattern for the Airport Technology and Air Navigation Technology study program to the D.IV program through the RPL type A route by applying the Blended Learning and nonboarding learning methods in the Mechatronics and Engineering study program Electricity can be implemented by taking education as much as $33-42$ credits. The number of practice credits is adjusted to the fulfillment of learning outcomes from each study program and the equalization of the curriculum from the D.III level of the Makassar Aviation Polytechnic is recognized as 100\% to be able to continue education over the level to D.IV of the Ujung Pandang State Polytechnic.

Keywords: Past learning cognition, Curriculum

\section{PENDAhULUAN}

Politeknik Penerbangan Makassar menerapkan Pendidikan system boarding school dengan jumlah program studi yang diselenggarakan berdasarkan data prediksi 3 tahun kedepan terkait kebutuhan tenaga penerbangan. Tiap akhir tahun, seluruh UPT melaporkan daya serap lulusannya ke Badan pengembangan SDM Perhubungan melalui PPSDMPU. Dan ditahun 2019 penyerapan lulusan UPT Perhubungan Udara mengalami penurunan, tahun 2020 kondisi ini diperparah dengan munculnya kasus Covid -19 sehingga lembaga pendidikan di pacu untuk berinovasi dalam menyalurkan lulusannya sehingga dapat terserap. Langkah yang dilakukan oleh UPT perhubungan udara tersebut adalah membuka peluang magang ataupun jalur PPNPN di beberapa Unit Pelaksana Bandar udara sekitar wilayah Indonesia Tengah dan Timur, serta membuka peluang Pendidikan lanjutan dari diploma III ke diploma IV dengan menjalin kerjasama.

Rekognisi Pembelajaran Lampau (RPL) sesuai dengan peraturan perundangan mempunyai dasar hukum berdasarkan Peraturan Menteri (Permen) Ristekdikti nomor 44 tahun 2015, kemudian Permen Ristekditi nomor 83 tahun 2013 yang merupakan salah satu dasar pelaksanaan RPL. Alih jenjang yang dulu dikenal sebagai istilah salah satu sistem pendidikan perguruan tinggi lanjutan, namun sekarang dinamakan sebagai RPL(rekognisi pembelajaran lampau) atau bisa disebut pendidikan sepanjang hayat. Sistem pendidikan saat ini telah mengenal jenjang atau level Kerangka Kualifikasi Nasional Indonesia (KKNI) untuk Pendidikan Vokasi (D3) adalah level 5 kemudian Sarjana Terapan (D4) atau S1 Terapan adalah level 6

Program kerjasama jalur Rekognisi Pelmbelajaran Lampau type A1 menjadi pilihan dikarenakan belum tersedianya program studi
Diploma IV di 7 (tujuh) UPT Perhubungan Udara, sehingga program kerjasama dengan politeknik dibawah naungan kementrian Pendidikan dan kebudayaan jalur RPL menjadi satu-satunya pilihan yang dapat dilakukan agar capaian daya serap lulusan dapat terwujud dan nilai penganguran dapat ditekan dengan mengembangkan kompetensi peserta didik yang sesuai dengan kompetensi dasar yang di peroleh pada jenjang Pendidikan diploma III.

\section{METODE}

Penelitian ini ditujukan untuk memperoleh data/informasi berdasarkan gambaran empiris tentang studi evaluasi program RPL kelas kerjasama bagi lulusan Pendidikan boarding dengan menggunakan metode CIPP. Adapun sumber data yang digunakan adalah sebagai berikut a. Data sekunder berupa data pemilik sertifikat kompetensi yang diperoleh dari Direktorat Jenderal Perhubungan Udara Kementerian Perhubungan dan data lulusan program Diploma III Program Studi Teknologi Navigasi Udara dan Teknologi Bandar udara Pusat Pengembangan Sumber Daya Manusia Perhubungan Udara dan b. Studi Kepustakaan (Library Research) yaitu teknik pengumpulan data sekunder yang berhubungan dengan masalah yang akan diteliti melalui buku - buku literature, Undang - Undang No.20 Tahun 2003 tentang Sistim Pendidikan Nasional, Undang - Undang Nomor 12 Tahun 2012 tentang Pendidikan Tinggi, Perpes No.8 Tahun 2012 tentang KKNI Permendikbut, Nomor 73 Tahun 2013 tentang Penerapam KKNI, Peraturan Menteri Riset Teknologi dan Pendidikan Tinggi Nomor 26 Tahun 2016 tentang Rekognisi Pembelajaran Lampau (RPL) serta media internet Yang memuat informasiinformasi yang berhubungan dengan objek permasalahan yang dikaji. 


\section{HASIL DAN PEMBAHASAN}

HASIL

Merujuk pada Peraturan Menteri Riset, Teknologi, dan Pendidikan Tinggi Nomor 26 Tahun 2016 tentang Rekognisi Pembelajaran Lampau, pasal 2 disebutkan bahwa RPL digolongkan menjadi 2 (dua) tipe:

1. RPL untuk melanjutkan pendidikan formal (tipe A)

Lulusan Diploma III jurusan Teknologi Navigasi Udara dan Teknologi Bandar Udara untuk melanjutkan pendidikan formal yang lebih tinggi (Tipe A) dapat menggunakan RPL untuk melanjutkan pendidikan formal (tipe A) guna mengajukan permohonan pengakuan kredit (satuan kredit semester/sks) atas $\mathrm{CP}$ yang telah dimilikinya untuk melanjutkan pendidikan ke jenjang yang lebih tinggi, sehingga yang bersangkutan tidak perlu mengambil semua sks. Setelah menyelesaikan sisa sks-nya di Poltekbang dapat memperoleh ijazah sesuai program yang diikutinya.

2. RPL untuk mendapatkan pengakuan kesetaraan dengan kualifikasi level KKNI tertentu (tipe B).

Lulusan Diploma III jurusan Teknologi Navigasi Udara dan Teknologi Bandar Udara untuk mendapatkan pengakuan kesetaraan dengan kualifikasi level KKNI tertentu (Tipe B) RPL untuk mendapatkan pengakuan kesetaraan dengan kualifikasi tertentu sesuai dengan level KKNI (tipe B) dapat digunakan perguruan tinggi untuk melakukan asesmen kepada individu, misalnya untuk mengetahui apakah pengalaman belajar atau kerjanya selama ini telah mencapai kesetaraan dengan CP pada program studi tertentu. RPL untuk mendapatkan pengakuan kesetaraan dengan kualifikasi tertentu (Tipe B) ini diperuntukkan untuk dosen serta pemohon yang bekerja di Poltekbang.

Dalam penelitian ini lebih berkonsentrasi pada RPL tipe A.

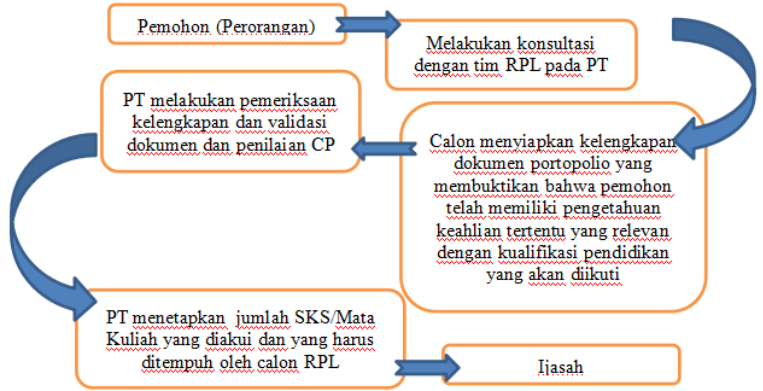

Gambar 1. Skematik RPL untuk melanjutkan pendidikan formal

(Tipe A)

Untuk memperoleh pengakuan kesetaraan dengan kualifikasi level KKNI tertentu Dari Gambar 1, nampak jelas bahwa pada RPL tipe A, seseorang tidak dapat langsung mendapatkan ijazah melalui RPL. Untuk memperoleh Ijazah, seseorang tetap harus melalui pendidikan tinggi agar yang bersangkutan dapat memperoleh nilai akademik dan CP secara utuh sebagaimana dipersyaratkan dalam Permenristekdikti No. 44 Tahun 2015 tentang Standar Nasional Pendidikan Tinggi.

Pembeda paling signifikan antara RPL untuk melanjutkan studi (tipe A) dengan RPL untuk pengakuan kesetaraan dengan kualifikasi level KKNI tertentu (tipe B) dapat disederhanakan sebagai berikut:

a. RPL Tipe A

berbasis pada inisiatif individu untuk memperoleh pengakuan dengan luaran akhir adalah ijazah.

\section{b. RPL Tipe B}

Berbasis pada inisiatif perguruan tinggi (untuk dosen) untuk memberikan pengakuan pada individu dengan luaran akhir adalah SK Penyeteraan.

Pembelajaran dan/atau pengalaman masa lampau yang bisa diakui pada RPL tipe A dapat berasal dari pendidikan formal lain yang diperoleh dari sebuah perguruan tinggi lain (tipe A1) atau berasal dari pendidikan non formal, informal dan/atau dari pengalaman kerja (tipe A2). Lingkup dan skema RPL dari pendidikan formal

1) RPL terhadap hasil belajar yang berasal dari pendidikan formal di perguruan tinggi (Tipe A1) sama dengan proses alih kredit (credit transfer). RPL tipe ini bertujuan untuk memfasilitasi mahasiswa yang pindah dari satu program studi ke program studi lainnya karena alasan perpindahan lokasi dan lainnya. 
2) RPL Tipe A1 dapat dilakukan oleh perguruan tinggi masing-masing melalui evaluasi transkrip dan silabus. Untuk melakukan hal ini, perguruan tinggi dipersilahkan mengatur proses ini dalam peraturan akademik. Walaupun proses ini sepenuhnya diserahkan kepada perguruan tinggi, penjaminan mutu input, proses, output, dan outcomes RPL ini wajib diperhatikan dan harus memenuhi Standar Nasional PendidikanTinggi.

Secara keseluruhan, proses ini dinyatakan pada Tabel berikut.

Tabel 1. Skema proses RPL dari hasil

belajarpendidikan formal di perguruan tinggi sebelumnya (Tipe A1)

\begin{tabular}{|c|c|c|c|c|c|}
\hline $\begin{array}{l}\text { RPL Type } \\
\text { A1 }\end{array}$ & $\begin{array}{l}\text { Hasil belajar } \\
\text { sebelumnya }\end{array}$ & $\begin{array}{c}\text { Metode } \\
\text { pengak } \\
\text { uan }\end{array}$ & $\begin{array}{c}\text { Hasil } \\
\text { pengaku } \\
\text { an }\end{array}$ & $\begin{array}{c}\text { Penye } \\
\text { lenggara }\end{array}$ & $\begin{array}{l}\text { Luaran } \\
\text { Akhir }\end{array}$ \\
\hline $\begin{array}{c}\text { RPL } \\
\text { Pendidikan } \\
\text { formal }\end{array}$ & $\begin{array}{l}\text { Pendidikan } \\
\text { formal di PT } \\
\text { lain melalui } \\
\text { evaluasi } \\
\text { transkrip dan } \\
\text { silabus }\end{array}$ & $\begin{array}{c}\text { Alih } \\
\text { Kredit }\end{array}$ & $\begin{array}{c}\text { SK } \\
\text { Pengaku } \\
\text { an Alih } \\
\text { Kredit }\end{array}$ & $\begin{array}{l}\text { PT dengan } \\
\text { program } \\
\text { studi } \\
\text { terakredita } \\
\text { si }\end{array}$ & Ijasah \\
\hline
\end{tabular}

3) Setelah memperoleh pengakuan atas jumlah sks yang dapat ditransfer dan mata kuliah apa saja yang dibebaskan, individu yang bersangkutan dapat melanjutkan pendidikannya di program studi yang dilamar dan bila menyelesaikan pendidikan tersebut, pemohon dapat memperoleh Ijazah.

\section{PEMBAHASAN}

\section{A. Rekognisi Pembelajaran Lampau}

Politeknik Penerbangan Makassar melaksanakan kerjasama dengan Politeknik Negeri Ujung Pandang untuk melaksanakan program Diploma IV kepada lulusan poltekbang prodi Teknologi Navigasi Udara dan Teknologi Bandar Udara. Legalitas yang dimiliki Politeknik Negeri Ujung Pandang pada Program D4 Program Studi Teknik Listrik telah terakreditasi oleh BAN PT dengan peringkat B, berdasarkan Surat Keputusan No. 0076/SK/BAN-PT/Akred/Dipl-IV/I/2017 yang berlaku hingga 10 Januari 2022 dan Program Studi Teknik Mekatronika, Jurusan Teknik Mesin dengan akreditasi B berdasarkan Keputusan Badan Akreditasi Nasional Perguruan Tinggi Nomor: 2791/SK/BANPT/Akred/Dipl-IV/X/2018.

Pendidikan Politeknik Program S1

Terapan Teknik Mekatronika merupakan pendidikan vokasi yang menghasilkan lulusan Sarjana Sains Terapan untuk mengisi kekosongan kerja pada bidang Teknik Mekatronika yang mencakup beberapa basis bidang ilmu dan keahlian keteknikan yang dipadukan pada suatu kurikulum dan silabus yang dituangkan dalam kompotensi lulusan.

1. Kompetensi Utama

Ada beberapa kemampuan mendasar yang sifatnya spesifik bagi tenaga engineering khususnya pada bidang Teknik Mekatronika yang sangat membantu pada saat mereka bekerja. Kemampuan mendasar sebagai bentuk elemen-elemen dasar pada kompetensi utama dapat dijabarkan sebabagi berikut :

a) Kemampuan mengumpulkan, menganalisa dan mengolah informasi

b) Kemampuan mengkomunikasikan ide dan informasi.

c) Mampu merencanakan dan mengelola kegiatan.

d) Dapat bekerjasama dengan orang lain (tim) dan bekerja mandiri.

e) Mampu memakai ide dengan dasar logika dan teknik matematika

f) Berusaha menyelesaikan masalah secara sistimatis

g) Mampu dengan mudah beradaptasi dan memahami budaya di mana dia bekerja.

Sesuai dengan misi dan tujuan program studi ini dan kemampuan dasar yang perlu dimiliki lulusan Teknik Mekatronika, maka kompetensi utama dari lulusan Teknik Mekatronika adalah sebagai berikut.

a) Mampu merancang dan membangun mesin otomatis skala kecil dengan menggabungkan perangkat mekanik dan elektronik.

b) Mampu merancang dan membangun sistem otomasi industri dan mekatronika untuk skala kecil dengan menggabungkan perangkat sensor, kontroller dan aktuator.

c) Mampu merancang dan membangun program untuk pendukung otomasi industri, robotika dan perangkat mekatronika lainnya dengan menggunakan berbagai macam aktuator; pneumatik / hidrolik / elektropneumatik / elektrohidrolik, dan motor listrik, serta dengan berbagai macam strategi pengontrolan; PLC, PID dan perangkat Mikrokontroller.

d) Mampu melakukan pemeliharaan dan perawatan sistem otomasi industri, mekatronika dan robotika. 
e) Mampu berwirausaha dalam bidang mekatronika.

f) Mampu mengoperasikan dan membuat benda kerja baik menggunakan mesin perkakas konvensional maupun Computer Numerical Control (CNC).

Selain kompetensi utama juga mengacu pada standar kompetensi yang dijabarkan oleh pihak industri sebagai pihak yang berpengalaman dalam mengembangkan sumber daya manusia dibidang sistim pembangkitan energi.

2. Kompetensi Pendukung

Selain dari kompetensi utama terdapat juga kompetensi pendukung yang dapat menambah nilai kinerja dari seorang tenaga engineering dalam mengemban tugas dan tanggung jawab secara baik. Nilai-kompetensi ini memang akan diajarkan secara langsung atau latihan-latihan praktis. Sebagai calon tenaga profesional maka perlu memperhatkan hai-hal: kejelasan tugas, inisiatif, mencari dan mendapatkan informasi, empati, berfikir analisa.dan percaya diri, serta berpikir konseptual.

Adapun Profil lulusan Program Studi D4 Teknik Listrik, antara lain:
1) Ahli Perancangan Sistem Distribusi Tegangan Menengah
2) Ahli Analisis Sistem Tenaga Listrik
3) Ahli Mendesain Kontrol Industri

\section{B. Alih Kredit / Penyetaraan Kurikulum}

Pelaksanaan kerjasama RPL untuk program studi D.IV mekatronika dan D.IV Teknik Listrik di PNUP maka dilakukan tahap penyetaraan kurikulum untuk MK yang telah ditempuh pada program D.III Poltekbang, dimana keseluruhan mata kuliah yang ditempuh di Poltekbang secara keseluruhan diakui oleh PNUP dikarenakan adanya isikan kompetensi dari MK tersebut.

Secara keseluruhan, Jumlah mata kuliah yang ditempuh selama pendidikan program Diploma IV jalur RPL ini untuk prodi Teknik Listrik dan teknik mekatronika dapat dilihat pada tabel 2 berikut
Tabel 2 Perhitungan SKS Lanjutan D.IV

\begin{tabular}{|c|c|c|c|c|}
\hline \multirow{2}{*}{ Tek. Listrik } & \multicolumn{2}{|c|}{ SKS } & \multicolumn{2}{|c|}{ JAM } \\
\hline & Teori & Praktek & Teori & Praktek \\
\hline \multirow{3}{*}{ Total } & 21 & 12 & 21 & 24 \\
\hline & $63.64 \%$ & $36.36 \%$ & $46.67 \%$ & $53.33 \%$ \\
\hline & \multicolumn{2}{|c|}{33} & \multicolumn{2}{|c|}{45} \\
\hline \multirow{2}{*}{ Mekatronika } & \multicolumn{2}{|c|}{ SKS } & \multicolumn{2}{|c|}{ JAM } \\
\hline & Teori & Praktek & Teori & Praktek \\
\hline \multirow{3}{*}{ Total } & 21 & 21 & 21 & 54 \\
\hline & $50 \%$ & $50 \%$ & $28 \%$ & $72 \%$ \\
\hline & \multicolumn{2}{|c|}{42} & \multicolumn{2}{|c|}{75} \\
\hline
\end{tabular}

(sumber : hasil penelitian)

Dari tabel diatas, tampak bahwa jumlah jam pelajaran untuk MK teori sebesar 1 JP sedangkan untuk MK Praktikum untuk Prodi Teknik Listrik sebesar 2 JP sedangkan untuk MK praktik Prodi Mekatronika sebesar 2-3 JP disesuaikan denganbeban Capaian Mata kuliah sehingga total JP praktik untuk Prodi Mekatronika den prodi Teknik Listrik tidak sama.

Secara detail sebaran MK yang ditempuh mahasiswa jalur RPL ini dapat dilihat pada tabel 3 dan 4 berikut: 
Tabel 3 Kurikulum RPL D.IV Program

Studi Teknik Mekatronika

Sumber : Hasil Penelitian.

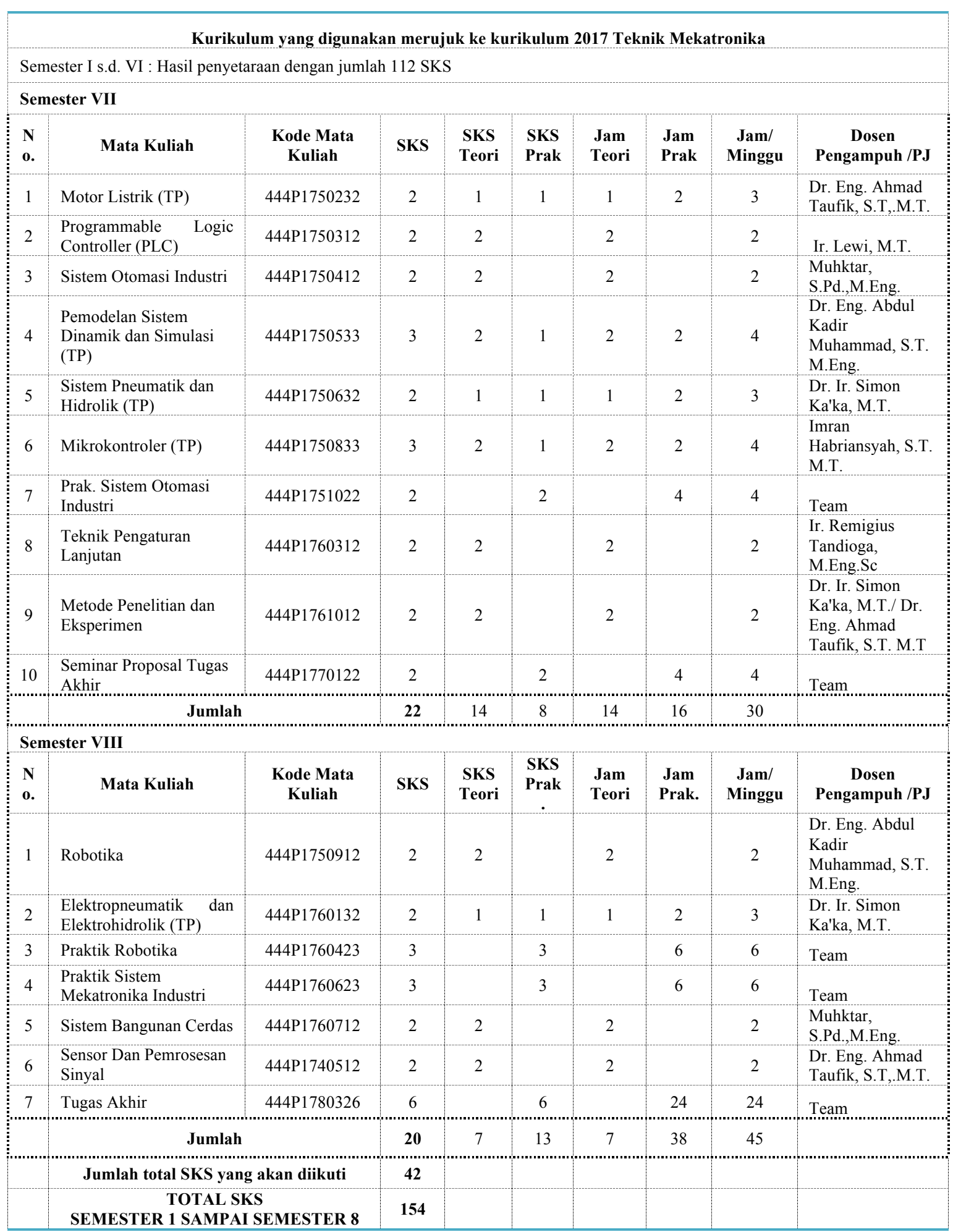


Tabel 4 Kurikulum RPL D.IV Program Studi Teknik Listrik

Semester 1 (VII)

\begin{tabular}{|c|c|c|c|c|c|c|}
\hline \multirow[t]{2}{*}{ No. } & \multirow[t]{2}{*}{ Kode MK } & \multirow[t]{2}{*}{ Mata Kuliah } & \multicolumn{2}{|c|}{ SKS } & \multicolumn{2}{|c|}{ JAM/MINGGU } \\
\hline & & & Teor & Praktek & Teori & Praktek \\
\hline 1 & $\begin{array}{c}421 \mathrm{P} 1750 \\
512\end{array}$ & $\begin{array}{c}\text { Pemilihan \& } \\
\text { Penggunaan Motor } \\
\text { Listrik }\end{array}$ & 2 & & 2 & \\
\hline 2 & $\begin{array}{c}421 \mathrm{P} 1750 \\
412\end{array}$ & $\begin{array}{l}\text { Analisis Sistem } \\
\text { tenaga listrik }\end{array}$ & 2 & & 2 & \\
\hline 3 & $\begin{array}{c}421 \mathrm{~J} 1710 \\
312\end{array}$ & $\begin{array}{l}\text { Proteksi Sistem } \\
\text { Tenaga Listrik }\end{array}$ & 2 & & 2 & \\
\hline 4 & $\begin{array}{l}421 \mathrm{P} 1760 \\
312\end{array}$ & $\begin{array}{l}\text { Audit Energi } \\
\text { Listrik }\end{array}$ & 2 & & 2 & \\
\hline 6 & $\begin{array}{c}421 \mathrm{P} 1760 \\
723\end{array}$ & $\begin{array}{c}\text { Praktikum } \\
\text { Pembangkit dan } \\
\text { Penyaluran STL }\end{array}$ & & 3 & & 6 \\
\hline 7 & $\begin{array}{c}421 \mathrm{P} 1770 \\
433\end{array}$ & $\begin{array}{l}\text { Automasi \& } \\
\text { Akuisisi Data }\end{array}$ & & 3 & & 6 \\
\hline 9 & $\begin{array}{c}421 \mathrm{P} 1770 \\
111\end{array}$ & Seminar Proposal & 1 & & 1 & \\
\hline & & Subtotal & 9 & 6 & 9 & 12 \\
\hline & & otal & & 15 & & 21 \\
\hline
\end{tabular}

Semester 2 (VII)

\begin{tabular}{|c|c|c|c|c|c|c|}
\hline \multirow[t]{2}{*}{ No. } & \multirow[t]{2}{*}{ Kode MK } & \multirow[t]{2}{*}{ Mata Kuliah } & \multicolumn{2}{|c|}{ SKS } & \multicolumn{2}{|c|}{$\begin{array}{c}\text { JAM/MINGG } \\
U\end{array}$} \\
\hline & & & Teori & Praktek & Teori & Praktek \\
\hline 1 & $\begin{array}{c}421 \mathrm{P} 1760 \\
512\end{array}$ & $\begin{array}{l}\text { Operasi Sistem } \\
\text { Tenaga Listrik }\end{array}$ & 2 & & 2 & \\
\hline 2 & $\begin{array}{c}421 \mathrm{P} 1770 \\
532\end{array}$ & $\begin{array}{c}\text { Komputasi Sistem } \\
\text { Tenaga Listrik }\end{array}$ & 2 & & 2 & \\
\hline 3 & $\begin{array}{c}421 \mathrm{P} 1770 \\
723\end{array}$ & $\begin{array}{l}\text { Praktikum } \\
\text { Distribusi dan } \\
\text { Proteksi } \\
\text { Tenaga Listrik }\end{array}$ & & 3 & & 6 \\
\hline 4 & $\begin{array}{c}421 \mathrm{P} 1750 \\
112\end{array}$ & Ekonomi Teknik & 2 & & 2 & \\
\hline 5 & $\begin{array}{c}421 \mathrm{P} 1740 \\
512\end{array}$ & Manajemen Proyek & 2 & & 2 & \\
\hline 6 & $\begin{array}{c}421 \mathrm{P} 1780 \\
323\end{array}$ & $\begin{array}{l}\text { Praktikum } \\
\text { Automasi }\end{array}$ & & 3 & & 6 \\
\hline 7 & $\begin{array}{c}421 \mathrm{P} 1780 \\
123\end{array}$ & Tugas Akhir & 4 & & 4 & \\
\hline & & Subtotal & 12 & 6 & 12 & 12 \\
\hline & & otal & & 18 & & 24 \\
\hline
\end{tabular}

(sumber: hasil penelitian)

Berdasarkan hasil penyetaraan kurikulum program D.III Politeknik Penerbangan Makassar dapat diakui sekitar 100 $\%$ atau keseluruhan kurikulum yang telah ditempuh setelah melalui proses penyamaan persepsi mata kuliah antar program studi alih jenjang RPL antara D.III Prodi Teknologi Navigasi Udara dengan D.IV Prodi Mekatronika serta antara D.III Prodi Teknologi Bandar Udara dengan D.IV prodi Teknik Listrik.

Pada tabel 3 dan tabel 4, tampak Mata Kuliah yang akan ditempuh alumni poltekbang yang mengikuti jalur RPL di PNUP selama 1 (Satu) tahun atau 2 (dua) semester Pelaksanaan pembelajaran menerapkan metode pembelajaran blended learning. Jumlah mata kuliah jalur RPL ini untuk prodi Teknik Listrik menempuh MK teori 63,64 \% dan 46,67 \% sedangkan teknik mekatronika menempuh MK Teori dan praktek masing-masing $50 \%$.

Secara singkat, jumlah SKS dan jam pelajaran yang wajib ditempuh lulusan poltekbang yang melanjutkan pendidikan D.IV jalur RPL dapat dilihat pada tabel 2 sedangkan secara detail kurikulum D.IV alih jenjang secara terperinci diuraikan pada tabel 3 untuk program studi Mekatronika dan tabel 4 untuk program studi Teknik Listrik.

\section{KESIMPULAN}

Pelaksanaan alih jendang dari program D.III dengan pola pendidikan system boarding program studi Teknologi Bandar Udara dan Teknologi Navigasi Udara ke program D.IV melalui jalur RPL type A dengan menerapkan metode pembelajaran Blended Learning dan non boarding pada program studi Teknik Mekatronika dan Teknik Listrik, dapat dilaksanakan dengan menempuh pendidikan sebanyak 33 - 42 SKS. Jumlah SKS praktik disesuaikan dengan pemenuhan capaian pembelajaran dari masing-masing program studi dan penyetaraan kurikulum dari jenjang D.III Politeknik Penerbangan Makassar diakui sebesar $100 \%$ untuk dapat melanjutkan pendidikan alih jenjang ke D.IV Politeknik Negeri Ujung Pandang.

\section{UCAPAN TERIMA KASIH}

Terima kasih disampaikan kepada Politeknik Penerbangan Makassar yang telah mendanai penelitian ini dan terima kasih pula kepada tim Politeknik Negeri Ujungpandang yang telah membantu dalam perolehan data penelitian serta dukungan dari lulusan Poltekbang atas nama Tomy yang ikut dalam program RPL ini.

\section{DAFTAR PUSTAKA}

Undang-Undang Nomor 20 Tahun 2003 Tentang Sistem Pendidikan Nasional.

Undang-Undang Nomor 14 Tahun 2005 Tentang Guru dan Dosen.

Undang-Undang Nomor 17 Tahun 2008 Tentang Pelayaran.

Undang-Undang Nomor 12 Tahun 2012 Tentang Pendidikan Tinggi. 
Peraturan Presiden Nomor 8 Tahun 2012 Tentang Kerangka Kualifikasi Nasional Indonesia.

Peraturan Menteri Pendidikan dan Kebudayaan Nomor 73 Tahun 2013 Tentang Penerapan Kerangka Kualifikasi Nasional Indonesia.

Peraturan Menteri Riset, Teknologi, dan Pendidikan Tinggi Nomor 26 Tahun 2016 Tentang Rekognisi Pembelajaran Lampau.

Keputusan Direktur Jenderal Pembelajaran dan Kemahasiswaan Kementerian Riset, Teknologi, dan Pendidikan Tinggi Republik Indonesia Nomor 123/B/SK/2017 Tentang Pedoman Tata Cara Penyelenggaraan Rekognisi Pembelajaran Lampau Direktur Jenderal Pembelajaran.

Direktorat Pembelajaran dan

Kemahasiswaan Direktorat Jenderal Pendidikan Tinggi Kementerian Pendidikan dan Kebudayaan Republik Indonesia Tahun 2014 tentang Panduan Pengusulan Ijin Penyelenggaraan Rekognisi PembelajaranLampau (RPL).

Direktorat Pembelajaran dan

Kemahasiswaan Direktorat Jenderal Pendidikan Tinggi Kementerian Pendidikan dan Kebudayaan Republik Indonesia Tahun 2014 tentang Panduan Pengusulan Ijin Pengakuan Tenaga Ahli Sebagai Dosen Melalui Mekanisme Rekognisi Pembelajaran Lampau.

Dr Wirawan, MSi, Sp.A,MM. M.Si, Buku Evaluasi Teori, Model, Standar, Aplikasi dan Profesi edisi revisi tahun 2011, ISBN: 978-979-769-383-1

Ismanto. "Evaluasi Hasil Belajar Pendidikan Agama Islam", Jurnal Edukasia Vol. 9, No. 2, (2014), 216

Dr.Haryanto, M.Pd, Evaluasi Pembelajaran, Yogyakarta: UNY Press, 2020), 95.ISBN : 978-602-498-148-8

Bustami, S.Si., M.Si., M.Kom.; Dahlan Abdullah, S.T., M.Kom.; Fadlisyah, S.Si., M.T. Buku Statistika; Terapannya pada Bidang Informatika, thn 2014 penerbit GRAHA ILMU

Nuryadi, S.Pd.Si., M.Pd Tutut Dewi Astuti, SE., M.Si, Ak., CA., CTA Endang Sri Utami, SE., M.Si., Ak., CA M. Budiantara, SE.,M.Si.,Ak, CA Buku Dasar-Dasar Statistik Penelitian tahun 2017 ISBN:
978-602-6558-04-6 penerbit SIBUKU MEDIA

Ghozali, Imam. 2011, Buku Aplikasi Analisis Multivariate dengan Program IBM SPSS 19. Semarang : Badan Penerbit Universitas Diponegoro

Hyland, Terry; Winch, Christopher, Guide to vocational education and training, URL page: http://hdl.voced.edu.au/10707/21 660. Published: New York, New York: Continuum International Publishing, 2007

Young, Jock (2011) The Criminological Imagination. Polity Press, Cambridge, 224 pp. ISBN 978-0-7456-4107-2.

Fitri Trapsilawati, Subagyo Subagyo, Teguh Ariyanto, Muhammad Kusumawan Herliansyah, Suryo Purwono, Evaluasi Sistem Penilaian Rekognisi Pembelajaran Lampau DOI: https://doi.org/10.20527/bpi.v2i3.4 9 Buletin Profesi Insinyur ISSN 26545926

A National Marketing Strategy for VET MEETING CLIENT NEEDS June 2000 ISBN 0642254355

Desamen Simatupang, Jaja Suparman, Sugiyanto, Ferry Budi Cahyon Junrla Meteor Marunda Jakarta 2017, Rekognisi Pembelajaran lampau (RPL) ejournal.stipjakarta.ac.id

Anthony J. Shinkfield, D.L. Stufflebeam, Teacher Evaluation: Guide to Effective Practice 1995 ISBN-13 : 978-0-7923-9674-1 DOI : 10.1007/978-94-009-1796-5 